\title{
Small and Medium-Scale Agro-Produce Entrepreneurship and Promotion of Non-Oil Exports from Nigeria
}

\author{
Eze, Felix John ${ }^{1,2}$, Odigbo, Ben E. ${ }^{2}$, Bassey, Agness Edem ${ }^{2}$ \\ ${ }^{1}$ Entreprenuership Development Centre \& Department of Marketing, University of Calabar, Nigeria \\ 2 Department of Marketing, University of Calabar, Nigeria \\ Correspondence: Odigbo, Ben E., Department of Marketing, University of Calabar, Nigeria.
}

Received: September 25, 2018

doi:10.5539/ibr.v11n11p164
Accepted: October 17, $2018 \quad$ Online Published: October 23, 2018

URL: https://doi.org/10.5539/ibr.v11n11p164

\begin{abstract}
The study undertook a critical appraisal of marketing communications' tools for the promotion of non-oil exports by small and medium-scale agro-produce entrepreneurs in Nigeria. It was motivated by the problem of low performance of the non-oil export sub-sector in the country. This is in spite of government's incentives and the introduction of African Growth and Opportunity Act (AGOA) in May 2000 by the United States of America, which was to improve export of products particularly in agriculture from Sub-Saharan Africa to the United States. The focus of AGOA was to enhance the economic growth of countries in Sub-Saharan Africa through export leverages rooted in the reduction of tariffs and non-tariff barriers. The specific objectives of the study were to: determine the effect of internet-marketing communications media as tools for promoting small and medium-scale farming entrepreneurs' non-oil exports from Nigeria; and ascertain the effect of social-media communications as tools for promoting small and medium-scale farming entrepreneurs' non-oil exports from Nigeria. Survey research design was adopted in the study. The sample frame comprised small and medium-scale agro-produce farmers drawn from three States representing the three-former regional structure of the country. Data sourced were statistically analyzed. Results indicate that both internet marketing and social media communications were not yet significant for promoting non-oil exports by small and medium-scale farming entrepreneurs from Nigeria, because of other serious diluting variables like poor products' quality, packaging, processing, storage and other systemic bottlenecks. It was then recommended that the Governments in sub-Saharan Africa, particularly Nigeria, should introduce and educate small and medium-scale agro-produce entrepreneurs wishing to go into non-oil exports, among other things, to improve their products' qualities to meet international markets' standards, before employing internet and social media marketing communications to create global awareness and demands for them.
\end{abstract}

Keywords: small-scale farming entrepreneurship, non-oil exports, internet-marketing, social- media marketing

\section{Introduction}

A critical review of Nigeria's revenue base reveals that the non-oil export sub-sector has continued to perform dismally since the 1970s till date. In spite of the various policies, strategies and reform programmes of government, the contributions of the sub-sector has been disheartening and far below expectations. Worse still, agriculture which served as the mainstay of the economy before the discovery of crude oil in the late 1960s has been relegated to the background and characterized by low productivity (Abogan, Akinola and Baruwa, 2014). This makes it difficult for small and medium-scale agro-produce entrepreneurs to contribute meaningfully to the nation's economic diversification policy and its non-oil exports drives, despite the introduction of the African Growth and Opportunity Act (AGOA) in May 2000 by the United States of America. AGOA was designed as an economic policy by the US government to assist in the export of products particularly in agriculture from Sub-Saharan African countries to the United States of America (Scheneidman and Lewis, 2012). The focus of AGOA was to encourage the economic growth of Sub-Saharan Africa countries through export leverage in the reduction of tariffs and non-tariff barriers as an incentive towards boosting trade relations with the United States of America (Akanji, 2007).

However, since its introduction, the AGOA has not really worked for the sub-Saharan African countries due to some systemic and structural problems inherent in those countries. Hence, the non-oil exports of countries like Nigeria, a key player in the region, is still abysmally low (Schneidman and Lewis, 2012). These include 
problems of poor products' standardization, low standard of processing, packaging, transportation and other physical distribution challenges, to meet international standards, especially the expectations of the US consumers and market.

\section{Statement of the Problem}

According to Eze, Ehikwe and Odigbo (2016), despite the fact that small and medium scale enterprises (SMEs) are the engines of economic growth in most developed and developing countries, they are usually the worst hit during periods of economic crises as was witnessed in Nigeria during the 2012 national flood disaster or during economic recessions, as being witnessed in the country since 2015 .

It was in order to assist African countries come out of such economic doldrums that the US government under Bill Clinton in year 2000, came up with a palliative policy called the African Growth and Opportunity Act (AGOA), aimed at boosting Africa non-oil exports especially to the US, in order to engender economic growth, employment generation and crime reduction in Sub-Saharan African countries. Unfortunately, export of agricultural produce from the concerned countries has not played a significant role in the accomplishment of their non-oil exports, with a contribution of less than $1 \%$ of AGOA exports. This is notwithstanding the fact that the agricultural sector has the largest potential to contribute to the national economies of sub-Saharan Africa. Nigeria is one of the countries whose non-oil exports have contributed very poorly under the AGOA programme (USITCT D, 2011; AKanji, 2007). Small and medium-scale farmers in the country, who account for over 85 percent of the country's agricultural output are the worst hit. Hence, this study is a critical appraisal of the effect of internet-marketing communications media and social-media communications as tools for promoting small and medium-scale farming entrepreneurs'non-oil exports from Nigeria, in order to fill the gaps in the contributions of non-oil exports to the optimization of AGOA benefits to Nigeria.

\section{Objectives of the Study}

The broad objective of the study is to appraise the effect of marketing communications as a tool for promoting small and medium-scale farming entrepreneurship for enhanced non-oil exports from Nigeria. The specific objectives include:

i. To determine the effect of internet-marketing communications media as tool for promoting small and medium-scale farmers non-oil exports from Nigeria.

ii. To ascertain the effect of social-media communications tools as vehicles for promoting small and medium-scale farmers non-oil exports from Nigeria.

\section{Research Questions}

The following research questions guided the study:

i. Will internet-marketing communications media be significantly effective as tool for boosting small and medium-scale farmers non-oil exports from Nigeria?

ii. To what extent will social-media communications tools serve as vehicles for boosting small and medium-scale farmers non-oil exports from Nigeria?

\section{Hypotheses}

The following null-hypotheses were tested in the study:

i. Internet-marketing communications media will not be significantly effective as tool for boosting small and medium-scale farmers non-oil exports from Nigeria.

ii. Social-media communications tools will not significantly serve as vehicles for boosting small and medium-scale farmers non-oil exports from Nigeria.

\section{Literature Review}

\subsection{Theoretical Framework}

The theoretical construct for this study hinges on the diffusion of innovation theory propounded by Everett Rogers, a professor of communication studies, in 1962. The theory seeks to explain how, why and at what rate new ideas and technology could be effectively introduced to a populace (Rogers, 2003). The theory explains how an innovation, idea, behaviour, or object especially a new technology-based idea is perceived and treated when introduced for the first time to a people (Pandey et. al., 2002). In doing this, the role of the media as well as interpersonal communication in providing information and influencing opinion and judgment of the target populace is critical for success (Lazarsfeld et. al, 2004). 
In explaining the diffusion theory, Rogers (2003) observed that there are four main elements that influence the spread of a new idea: the innovation, communication channels, time and a social system. Rogers (2003) proposes that these five main elements influence the spread of a new idea. An innovation is an idea, practice or object that is perceived as new by an individual or other unit of adoption (the words innovation and technology are used as synonyms). Communication is a process in which participants share new information with one another in order to reach a mutual understanding. Communication channels allow the transfer of information from one unit to the other. Communication patterns or capabilities must be established between parties as a minimum for diffusion to occur.

The passage of time is necessary for innovations to be adopted; new innovations are rarely adopted instantaneously (Rogers 2003). Adopters are the minimal unit of analysis and include individuals, organizations, institutions, businesses, schools, hospitals, etc within a social system.

\section{Five Stages in the Decision Innovation Process}

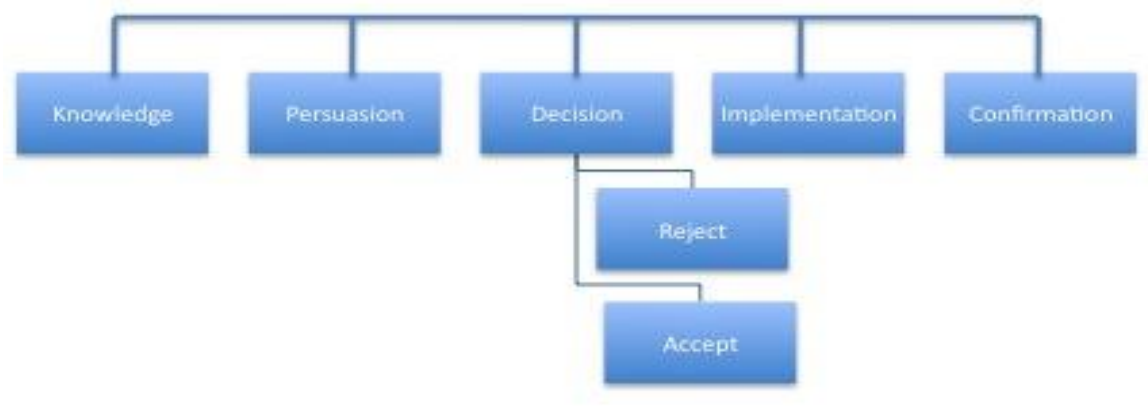

Figure 1. Stages in the diffusion decision-making process

Source: Rogers, E. M. (2003), Diffusion of innovations (5th edition). New York, NY: Free Press.

According to Rogers (2003), new ideas possess a degree of uncertainty and thus are perceived as risky. Therefore, individual can reduce such uncertainty by obtaining information about the new innovation. Diffusion occurs through a five-step decision-making process: - awareness, interest, evaluation, trial, and adoption. However, in a later study Rogers (2003) modified the terminology of the five stages to - knowledge, persuasion, decision, implementation, and confirmation. However, the descriptions of the five new categories are similar to the first five earlier outlined (See figure 1 for the new categories).

Rogers (2003) identified five (5) categories of adopters: the innovators, early adopters, early majority, late majority, and laggards. These categories of adopters are depicted in figure 3. According to Rogers, the individuals within a social system do not adopt an innovation at the same time. Individuals are classified into adopter categories on the basis of the time it takes them to make final decisions to adopt a new idea, as shown in figure 2 .

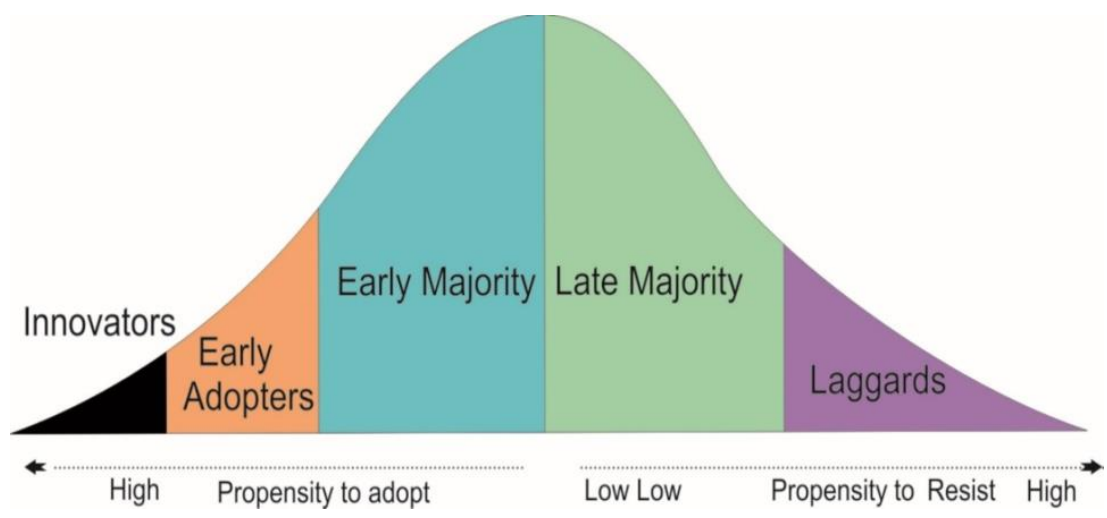

Figure 2. Five categories of adopters and their degree of influence

Source: Rogers Everett M. (2003), Diffusion of Innovations, $5^{\text {th }}$ Ed., Free Press, New York, p221. 
Rogers model then described five conditions that affect the adoption process of a new innovation or technological idea to include - Relative Advantage, Compatibility, Complexity, Observability and Trailability. Relative Advantage explains the degree to which the new idea is perceived as more beneficial by adopters comparative to other alternatives. That is to say, is the new technology perceive to be better than the old one? The greater the perceived relative advantage of the new idea, the more rapid its rate of adoption by the target audience (Bell, 2003; Katz \& Lazarsfeld, 2005).

Compatibility means the degree to which an innovation is perceived as being fit to the potential adopters' cultural and social norms, values, past experiences, present needs, style (Valente, 2006). When an idea is incompatible with people's values, norms or practices it will not be adopted as quickly as one that is compatible with their values, norms or practices.

Complexity relates to the extent to which the innovation is easy to used and understood by the adopters. New technologies that are perceived to be easier to be used and less complex to understand possess higher possibility of adoption by potential users (Rogers, 2003). In other words, complex ideas or difficult-to-apply ideas are most likely to be shunned by the target audience. On the other hand, Trailability means the degree to which an innovation adopter can test and assess the innovation before fully adopting or implementing it or rather, the degree to which an innovation may be experimented by the users on a limited basis prior to committing to its actual usage. An innovation that is trialable represents less uncertainty to the individual who is considering it. Finally, Observability translates relates to the level to which the results of innovation are visible to others in the social system. Observability has significant effect on the rate of adoption by the target audience (Schiffman and Kanuk, 2004).

\subsection{Nigeria's Non-Oil Export Profile: A Historical Review}

According to the Central Bank of Nigeria (CBN), before independence and in the early 1960s, agriculture was the main stay of the Nigerian economy and the country's chief foreign exchange earner. It accounted for well over 80 percent of the export earnings, 75 percent of employment; 65 percent of the GDP and about 50 percent of the total government revenue. Agriculture contributed 50\% to the nation's GDP in 1970 and 34\% in 2003 (CBN, 2007). In the 1960's Nigeria's export trade was dominated by non-oil products such as groundnuts, palm kernel, palm oil, cocoa, rubber, cotton, coffee, copra, beniseed, hides and skin, cattle and many more. This was complimented by solid minerals like tin ore, columbite and gems. These products accounted for over $66 \%$ of nation's total exports earnings up until the early 1970s when the oil boom set in. In fact, reports had it that cocoa was the dominant export product at that time, contributing about $15 \%$ of total exports in 1970. Unfortunately, however, during the oil boom era which began in 1973/74 and continued till the 1980s, the country's export basket was dominated by earnings from oil (Ogunkola et al., 2008).

Meanwhile, towards the early and mid-1980s, a global oil glut caused a deep distress to the nation's economy with a drastic reduction in its foreign exchange earnings from oil export. By then, agriculture has been significantly abandoned, contributing quite insignificantly to the country's non-oil export basket. Since, then the people of Nigeria have found it difficult to re-discover the magic wand of the agricultural sector of the 1960s and 1970s. The massive increase in oil revenue, followed by massive investments in socio-economic infrastructure led to the migration of many able-bodied young men and women from the hinter land to the urban areas and cities, leading to a new-found western lifestyle characterized by white-collar job syndrome and total abandonment of farming. Thus, despite the various governmental policies, strategies and reform programmes, the contributions of the agriculture sub-sector to the country's total foreign exchange earnings since the past twenty years have been dismal and disheartening.

According to reports, the output of export crops grew at an average annual rate of 4.7\% in 1950-1957 and 7.4\% in 1960-1965, then declined by $17.3 \%$ in 1970-1975. The transformation of Nigeria from a net exporter of agricultural produce to a large-scale importer of the same commodities was particularly marked during the period 1973-1982. The efforts to reverse these trends seem to be yielding little or no results, as oil continues to dominate the country's exports. Non-oil exports share of Nigeria's total exports have remained under $5 \%$ for most years since the introduction of the structural adjustment programme SAP in the 980s (Abogan, Akinola and Baruwa, 2014).

Although agriculture no longer serves as the leading contributor to Nigeria's gross national product and leading foreign exchange earner due to the discovery and phenomenal growth in petroleum sector of the economy, agriculture is still the dominant economic activity in terms of employment and linkages with the rest of the economy. Agriculture still accounts for one-third of the nation's GDP, and remains the leading employment sector of the vast majority of the Nigerian population, as it employs two-third of the labour force (Chigbu, 2000). 
However, its contribution to non-oil exports remains abysmally poor and unsatisfactory.

\subsection{Youths and Small and Medium-Scale Agro-Produce Entrepreneurship for Non-Oil Exports in Nigeria}

Eze, Odigbo and Ehikwe (2016) observed that a Central Bank of Nigeria's 2014 report documented that 80 per cent of Nigerian youths were without jobs in between 2012 to 2014 (CBN, 2014). This is despite repeated figures released by the National Bureau of Statistics indicating that the Nigerian economy was experiencing positive growth rate within that period. The National Bureau of Statistics (NBS) on its own admitted that 54 per cent of Nigerian youths were unemployed in 2012. This was contained in the "2012 National Baseline Youth Survey Report" issued in Abuja by the NBS in collaboration with the Federal Ministry of Youth Development (NBS, 2013). Figure 3 in this text from Rise Network (2013), shows that the country's overall unemployment rate in 2011 was 23.9 percent, with youths' unemployment accounting for over 50 percent of that.

The concomitant effect of the growing level of youth unemployment in Nigeria, is the exacerbation of hopelessness, restiveness and feelings of frustration amongst the youths, often precipitating acts of violence and conflicts in the country. This is happening in the face of high population growth rate amid unsatisfactory economic performance which compounds the problem of youth's unemployment in the country (Eze, Odigbo \& Ehikwe, 2016; Omeje, 2005). Omeje (2005) adds that there is a markedly unfavourable imbalance between Nigeria's population growth rate and its economic performance. He advised that the expansion of the economy to create employment opportunities for young school leavers and graduates through export-based small and medium-scale farming entrepreneurship could be one of the viable answers to the problem. This is because massive youths' unemployment in any country heightens the risk of anti-government and anti-establishment behavior in society. The frustration and vulnerability of the youths make it possible for them to be recruited, inspired or hired for violence with relative ease by disgruntled and dubious politicians and religious fanatics. In the midst of mass misery and poverty, violence is also seen and promoted as an economic opportunity for luring the jobless youths by some terrorist organizations. This phenomenon resonates with the greed versus grievance theory of Paul Collier \& Anke Hoeffler (2002).

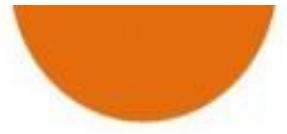

And within the next decade a further one billion people will come of working age.

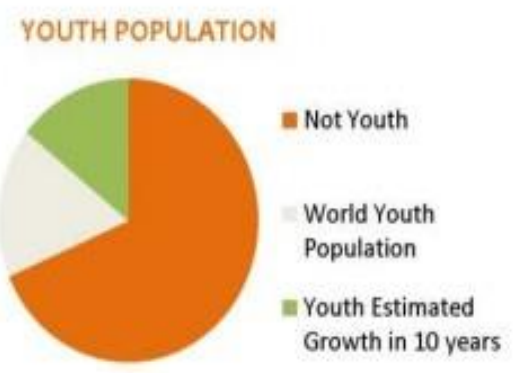

Young people are the next generation of potentially productive economic and social at 12.7 per cent in 2012 .

\section{UNEMPLOYMENT RATE IN NICERIA}

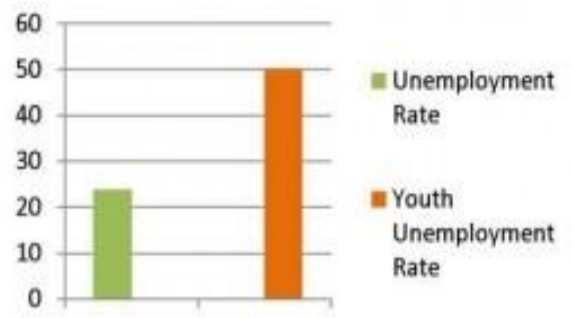

Nigeria's unemployment rate for the year 2011

was at 23.9 percent with youth

unemployment rate at over 50 percent

16\% UNEMPLOYMENT CROWTH RATE

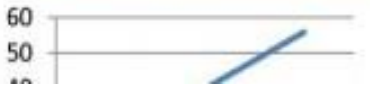

Figure 3. Source: Rise Network (2013), Youth Unemployment In Nigeria: Shocking Statistics, Facts And Why

The Future May Not Be So Bright After all

http://risenetworks.org/2013/05/16/youth-unemployment-in-nigeria-is-there-hope-for-nigerian-youth/

It was mindful of this disturbing fact that the incumbent Nigeria President, Gen. Muhammadu Buhari, announced in 2015 that he was going to launch a massive graduates' agricultural programme. That his government will collaborate with States and Local Governments to innovatively fund youths in commercial agribusiness programmes and launch Agricultural Support Programmes that will drive agricultural land 
development and mechanization (Nigerianmonitor, 2015; Newsheadline, 2015). However, as at the time of this report in 2017, the programme still remains in the drawing board.

\subsection{Internet and Social Media for Non-Oil Exports in Sub-Saharan Africa}

Internet marketing or eMarketing is any marketing done online via websites or other online tools and resources. In trading or marketing terms, it refers to the application of marketing principles and techniques via electronic media and more specifically the Internet. The terms eMarketing, Internet marketing and online marketing, are frequently used interchangeably, and thus, often considered synonymous (Odigbo, Ugwu Ogbu \& Ekemezie, 2017).

Social media marketing on the other hand, is the application of internet community platforms like Twitter, Facebook, LinkedIn, Instagram, WhatsApp, YouTube, Wiki sites, Four Square, Instant Messaging and others to reach out to target audiences. African farmers wishing to go into export can use it to find customers, businesses, promote products and services, in the social communities they are seeking recommendations from their foreign social friends. Social media are media that facilitate communication and sharing of information through social networks (Odigbo, Ugwu Ogbu \& Ekemezie, 2017).

\section{Methodology}

Survey design was adopted in the study. Data were sourced through structured-questionnaire administered on farmers selected from three regions of the country: North, South-West and South-East in accordance with the three-former regional structure of the country. The study population was 80,000 farmers. A sample size of 270 farmers was judgmentally determined and proportionally apportioned at 90 per region. Representative sample States chosen from the three regions were: Benue State reputed as the food basket of the nation, from the North; Ebonyi State from the South-East and Ondo State from the South-West. Purposive sampling technique was also employed in administering the questionnaire. 254 of the questionnaire copies administered, representing $94.07 \%$ were returned by the respondents. The data sourced were analyzed with the chi-square $\left(\mathrm{X}^{2}\right)$ statistical tool.

\section{Data Presentation and Analysis}

\subsection{Demographic Profiles of the Respondents}

Data from the field indicate that $63.78 \%$ of the respondents were male, while $36.22 \%$ were female. $14.71 \%$ were in the age bracket of 21 to 30 years, $34.25 \%$ in the age group of 31 to 40 years; $36.61 \%$ were in the age range of 41 to 50 years, while the remaining $14.96 \%$ were 51 years or above. $48.42 \%$ had First School Leaving O'Level certificates; $19.29 \%$ had National or Higher National diplomas; $19.92 \%$ had First degrees, while the remaining $15.35 \%$ had postgraduate degrees. $20.08 \%$ specialized in tubers production, $14.57 \%$ were cocoa farmers, $11.81 \%$ were palm oil processors and marketers, $20.47 \%$ were into the production of various kinds of cereals, $4.72 \%$ were cashew nuts marketers, $4.33 \%$ were into the sales of various kinds of African spices and sheanuts, while the remaining $24.01 \%$ were into other unclassified farming types (see figure 4 below for a graphical presentation of the respondents' farming specializations).

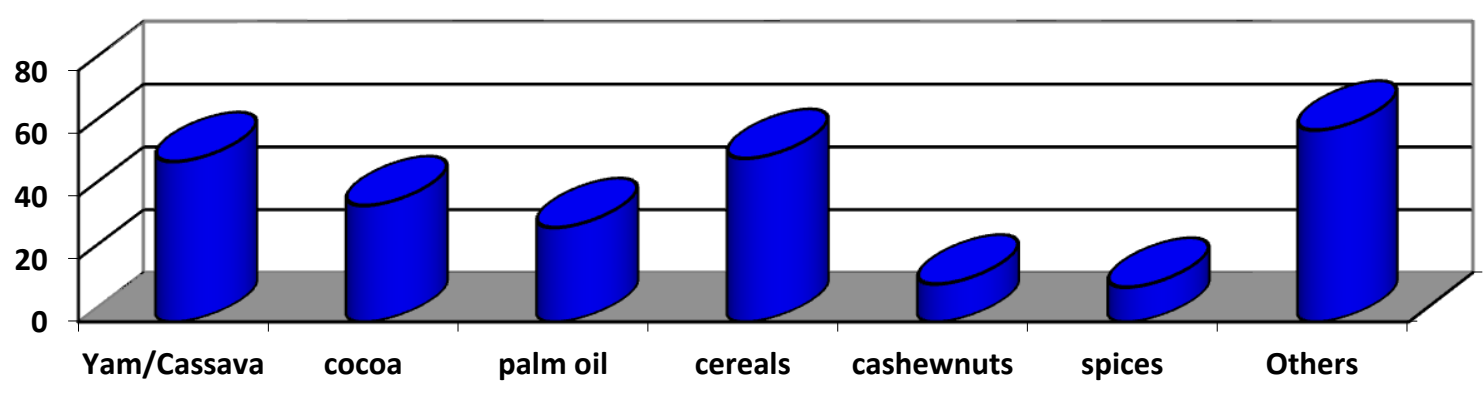

Figure 4. Respondents' farming specializations 
Table 1. Respondents' levels of belief on the effect of internet-marketing communications media of E-mails as tool for promoting small and medium-scale farmers' non-oil exports from Nigeria

\begin{tabular}{lll}
\hline Options & Frequency & Percent \\
\hline Strongly Agree & 37 & $14.57 \%$ \\
Agree & 33 & $12.99 \%$ \\
Undecided & 35 & $13.78 \%$ \\
Disagree & 71 & $27.95 \%$ \\
Strongly Disagree & 78 & $30.71 \%$ \\
Total & 254 & $100 \%$ \\
\hline
\end{tabular}

Source: Field survey, 2017.

Data on table 2 reveal that only $14.57 \%$ of the respondents strongly agreed that internet-marketing communications media of E-mails will be significantly effective as tool for promoting small and medium-scale farmers' non-oil exports from Nigeria. $12.99 \%$ equally agreed with that; $13.78 \%$ were not quite sure; $27.95 \%$ disagreed with that, while the remaining $30.71 \%$ strongly disagreed with the point. See figure 5 below for a graphic picture of these results.

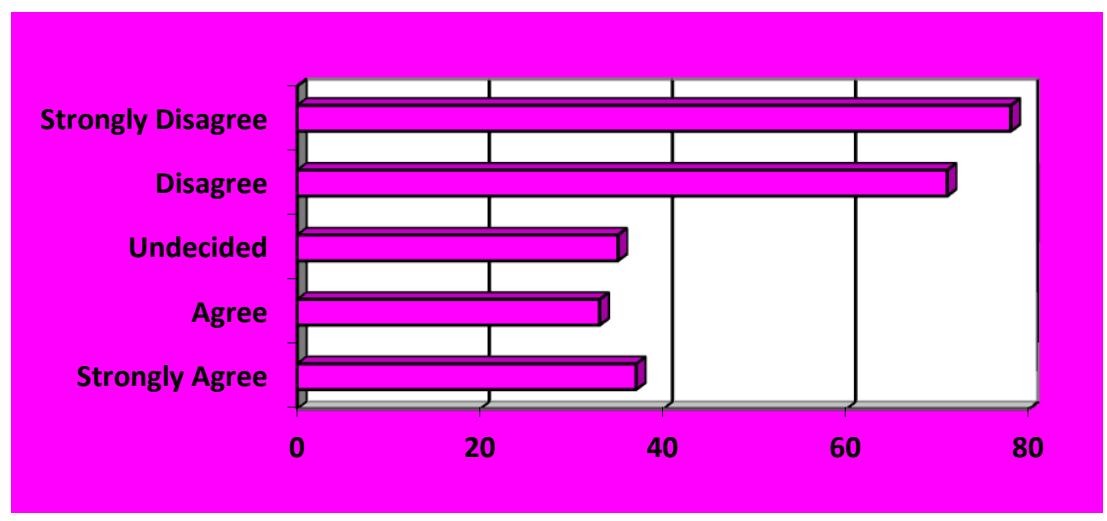

Figure 5. Respondents' levels of beliefs on the effect of internet-marketing communications media of E-mails

Table 2. Effect of internet-marketing communications media of websites as tool for promoting small and medium-scale farmers non-oil exports from Nigeria

\begin{tabular}{lll}
\hline Options & Frequency & Percent \\
\hline Strongly Agree & 41 & $16.14 \%$ \\
Agree & 43 & $16.93 \%$ \\
Undecided & 33 & $12.99 \%$ \\
Disagree & 67 & $26.38 \%$ \\
Strongly Disagree & 70 & $27.56 \%$ \\
Total & 254 & $100 \%$ \\
\hline
\end{tabular}

Source: Field survey, 2017.

Data on table 3 reveal that $16.14 \%$ of the respondents strongly agreed that internet-marketing communications media of website marketing will be significantly effective as tool for promoting small and medium-scale farmers' non-oil exports from Nigeria. $16.93 \%$ equally agreed with that; $12.99 \%$ were not quite sure; $26.38 \%$ disagreed with that, while the remaining $27.56 \%$ strongly disagreed with the point. See figure 6 below gives a graphic picture of these results.

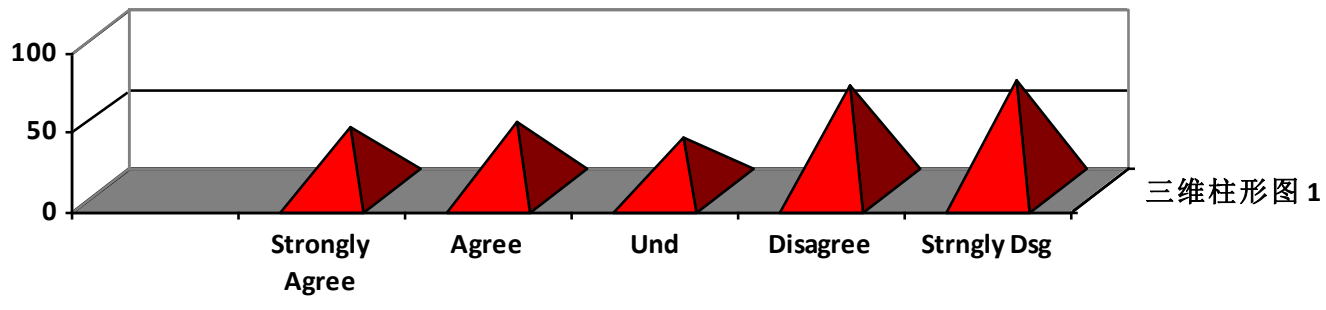

Figure 6. Effect of internet-marketing communications media of websites... 
Table 3. Respondents' views on effect of social-media non-video communications networks as vehicles for promoting small and medium-scale farmers' non-oil exports from Nigeria

\begin{tabular}{lll}
\hline Options & Frequency & Percent \\
\hline Strongly Agree & 34 & $13.38 \%$ \\
Agree & 42 & $16.53 \%$ \\
Undecided & 33 & $12.99 \%$ \\
Disagree & 67 & $26.38 \%$ \\
Strongly Disagree & 78 & $30.71 \%$ \\
Total & 254 & $100 \%$ \\
\hline
\end{tabular}

Source: Field survey, 2017.

Data displayed on table 3 indicate that $13.38 \%$ of the respondents strongly agreed that social-media non-video communications networks will be significantly effective as vehicles for promoting small and medium-scale farmers' non-oil exports from Nigeria. $16.53 \%$ of the respondents equally agreed with that; $12.99 \%$ were not quite sure; $26.38 \%$ disagreed, while the remaining $30.71 \%$ totally disagreed with the point. Figure 7 below for a graphic picture of this result.

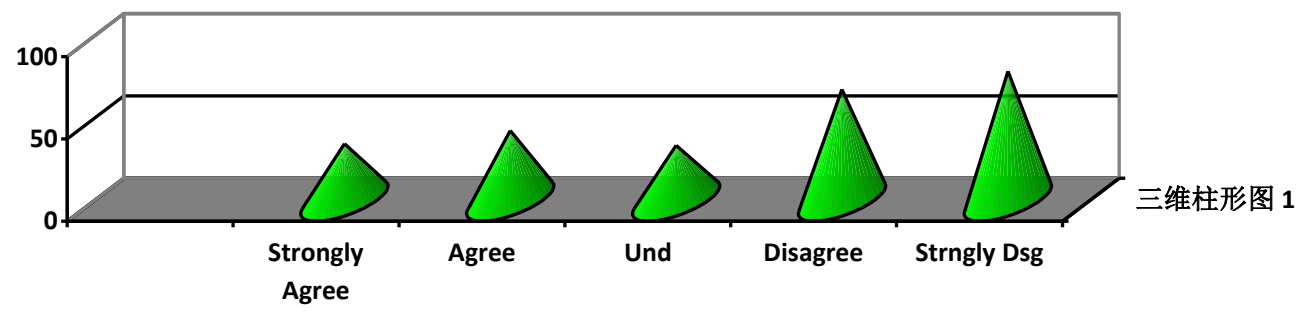

Figure 7. Effect of social-media communications tools as vehicles for promoting small and medium-scale farmers' non-oil exports from Nigeria

Table 4. Respondents' views on effect of social-media video communications networks as vehicles for promoting small and medium-scale farmers' non-oil exports from Nigeria

\begin{tabular}{lll}
\hline Options & Frequency & Percent \\
\hline Strongly Agree & 45 & $17.72 \%$ \\
Agree & 56 & $22.05 \%$ \\
Undecided & 31 & $12.99 \%$ \\
Disagree & 63 & $24.80 \%$ \\
Strongly Disagree & 59 & $23.22 \%$ \\
Total & 254 & $100 \%$ \\
\hline
\end{tabular}

Source: Field survey, 2017.

Data on table 5 indicate that $17.72 \%$ of the respondents strongly agreed that social-media video communications networks like the YouTube will be significantly effective as vehicles for promoting small and medium-scale farmers' non-oil exports from Nigeria. $22.05 \%$ of the respondents equally agreed with that; $12.99 \%$ were undecided; $24.80 \%$ disagreed, while the remaining $23.22 \%$ strongly disagreed with the point. Figure 8 gives a graphic picture of these results.

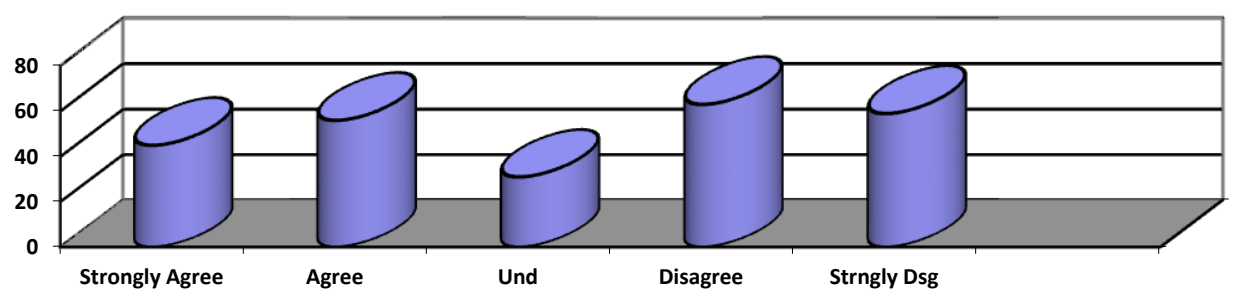

Figure 8. Effect of social-media video communications networks as vehicles for promoting small and medium-scale farmers' non-oil exports from Nigeria 


\section{DATA ANALYSIS}

The data procured in this study were analyzed with the statistical tool of Likert's 5-points scale.

\section{Test of Hypothesis 1:}

Ho: Internet-marketing communications media will not be significantly effective as tool for boosting small and medium-scale farmers non-oil exports from Nigeria.

Hi: Internet-marketing communications media will be significantly effective as tool for boosting small and medium-scale farmers non-oil exports from Nigeria.

\section{Test Statistics $=$ Measure of Central Tendency (Mean) \\ DECISION RULE:}

If Mean $<2.5$, the Respondents Disagree

If $3.5<$ Mean $\leq 2.5$, the Respondents are Undecided

If Mean $\geq 3.5$, the Respondents Agree

Table 5. Effect of internet-marketing communications media

\begin{tabular}{|c|c|c|c|c|c|c|c|c|}
\hline $\mathbf{S} / \mathbf{N}$ & Questions & SA & $\mathbf{A}$ & Ud & D & SD & Mean & Decision \\
\hline 2 & $\begin{array}{l}\text { Effect } \\
\text { internet-marketing } \\
\text { communications media of } \\
\text { E-mail as tool for } \\
\text { promoting small and } \\
\text { medium-scale farmers } \\
\text { non-oil exports from } \\
\text { Nigeria }\end{array}$ & $\begin{array}{l}37 \\
(185)\end{array}$ & $\begin{array}{l}33 \\
(132)\end{array}$ & $\begin{array}{l}35 \\
(105)\end{array}$ & $\begin{array}{l}71 \\
(142)\end{array}$ & $\begin{array}{l}78 \\
(78)\end{array}$ & 2.53 & Undecided \\
\hline 3 & $\begin{array}{l}\text { Effect } \\
\text { internet-marketing } \\
\text { communications media of } \\
\text { websites as tool for } \\
\text { promoting small and } \\
\text { medium-scale farmers } \\
\text { non-oil exports from } \\
\text { Nigeria } \\
\text { GRAND MEAN = }\end{array}$ & $\begin{array}{l}41 \\
(205)\end{array}$ & $\begin{array}{l}43 \\
(172)\end{array}$ & $\begin{array}{l}33 \\
(99)\end{array}$ & $\begin{array}{l}67 \\
(134)\end{array}$ & $\begin{array}{l}70 \\
(70)\end{array}$ & 2.68 & Undecided \\
\hline
\end{tabular}

Result Interpretation: Research Objective 1 is tested with questions on tables 1 and 2 on the Likert's table. Question 2 on whether internet-marketing communications media of E-mail will be significantly effective as tool for promoting small and medium-scale farmers non-oil exports from Nigeria produced a Mean of 2.53 which is < 3.50, hence, the farmers were uncertain. Question 3 on whether internet-marketing communications media of websites will be significantly effective as tool for promoting small and medium-scale farmers non-oil exports from Nigeria, also produced a Mean of 2.68 which is $<3.50$, hence, the farmers were again uncertain. These two results cumulatively produced a grand mean of 2.60 , thereby indicating that the farmers are not yet certain that the application of internet marketing media will boost their non-oil export, and thus, acceptance of the null-hypothesis which says that: "Internet-marketing communications media will not be significantly effective as tool for boosting small and medium-scale farmers non-oil exports from Nigeria."

\section{Test of Hypothesis 1:}

Ho: Social-media communications tools will not significantly serve as vehicles for boosting small and medium-scale farmers non-oil exports from Nigeria.

Hi: Social-media communications tools will significantly serve as vehicles for boosting small and medium-scale farmers non-oil exports from Nigeria.

\section{Test Statistics $=$ Measure of Central Tendency $($ Mean)}

\section{DECISION RULE:}

If Mean < 2.5, the Respondents Disagree

If $3.5<$ Mean $\leq 2.5$, the Respondents are Undecided

If Mean $\geq 3.5$, the Respondents Agree 
Table 6. Effect of social media marketing communications channels

\begin{tabular}{|c|c|c|c|c|c|c|c|c|}
\hline $\mathbf{S} / \mathbf{N}$ & Questions & SA & $\mathbf{A}$ & Ud & D & SD & Mean & Decision \\
\hline 4 & $\begin{array}{l}\text { Effect of social-media } \\
\text { non-video } \\
\text { communications networks } \\
\text { as vehicles for promoting } \\
\text { small and medium-scale } \\
\text { farmers' non-oil exports } \\
\text { from Nigeria }\end{array}$ & $\begin{array}{l}34 \\
(170)\end{array}$ & $\begin{array}{l}42 \\
(168)\end{array}$ & $\begin{array}{l}33 \\
(99)\end{array}$ & $\begin{array}{l}67 \\
(134)\end{array}$ & $\begin{array}{l}78 \\
(78)\end{array}$ & 2.55 & Undecided \\
\hline 5 & $\begin{array}{l}\text { Effect of social-media } \\
\text { video communications } \\
\text { networks as vehicles for } \\
\text { promoting small and } \\
\text { medium-scale farmers' } \\
\text { non-oil exports from } \\
\text { Nigeria } \\
\text { GRAND MEAN = }\end{array}$ & $\begin{array}{l}45 \\
(225)\end{array}$ & $\begin{array}{l}56 \\
(224)\end{array}$ & $\begin{array}{l}31 \\
(93)\end{array}$ & $\begin{array}{l}63 \\
(126)\end{array}$ & $\begin{array}{l}59 \\
(59)\end{array}$ & 2.86 & Undecided \\
\hline
\end{tabular}

Result Interpretation: Research Objective 2 is tested with questions on tables 3 and 4 on the Likert's table. Question 4 on whether social-media non-video communications networks will be significantly effective as vehicles for promoting small and medium-scale farmers' non-oil exports from Nigeria produced a Mean of 2.55 which is $<3.50$, hence, the farmers were uncertain. Question 5 on whether social-media video communications networks will be significantly effective as vehicles for promoting small and medium-scale farmers' non-oil exports from Nigeria, also produced a Mean of 2.86 which is $<3.50$, hence, the farmers were again uncertain. These two results cumulatively produced a grand mean of 2.71 , thereby indicating that the farmers were not yet certain that the application of social media networks marketing communications will boost their non-oil exports, and thus, acceptance of the null-hypothesis which says that: "Social-media communications tools will not significantly serve as vehicles for boosting small and medium-scale farmers non-oil exports from Nigeria."

\section{Summary of Findings and Their Implications}

A summary of the results of this study indicate that:

i. Internet-marketing communications media will not be significantly effective as tool for boosting small and medium-scale farmers non-oil exports from Nigeria.

ii. Social-media communications tools will not significantly serve as vehicles for boosting small and medium-scale farmers non-oil exports from Nigeria.

The implications of these results is that the applications of internet-marketing communications media and social-media communications networks are not enough for the boosting of Nigeria's small and medium-scale farmers non-oil exports. These results agree with the findings of Schneidman and Lewis (2012), that the challenges inhibiting most sub-Saharan countries from successful non-oil exports include poor products' quality, low standard of processing, packaging, transportation and other physical distribution requirements that needed improvement to enhance the value of both their primary produce and secondary products for export. So, these problems and more increases their inability to meet the expectations of the international markets and consumers.

Thus, there is need for a technical training and capacity building of the farmers in products' standardization, market research, information gathering, market intelligence for improved international business success. The essence is to guarantee quality that will meet the expectations of consumers in the international markets (Kimberlie and Wallace, 2004). The storage and packaging challenges for agricultural produce is yet another problem confronting exporters from sub-Saharan Africa. The recent experience where a container load of yams from Nigeria, shipped to London all got rotten before they got there is a case in point ( ). Time and timing is of essence here, because of the short shelf-life of agricultural produce.

\section{Recommendations}

Based on the findings of this study it is recommended as follows:

i. Governments in Sub-Saharan African countries like Nigeria should organize periodic national training campaigns for farmers in the country, in order to boost their capacity for non-oil exports to the international markets.

ii. The small and medium-scale farmers should band themselves into cooperatives in order to attract micro-credits from funding organizations. This will also help them to gather market intelligence and information cooperatively, at lesser costs to each of them. 
iii. Governments of countries in Sub-Saharan Africa, including Nigeria, should also form agencies whose duty it will be to educate and supervise farmers wishing to go into export on how to improve their products' qualities, packaging, processing, storage, standardization, sorting and grading, to meet international markets' demands.

iv. Farmers in Sub-Saharan Africa, including Nigeria, should also be enlightened and well-tutored on how to employ modern marketing communications media like the internet and social media in creating awareness and demands for their products.

\section{References}

Abogan, O. P., Akinola, E. B., \& Baruwa, O. I. (2014). Non-oil export and Economic growth in Nigeria (1980-2011). Journal of Research in Economics and International Finance, p.1-11, January.

Akanji, O. O. (2007). Africa growth and opportunity act and Africa agriculture. Paper prepared for presentation at the farm management association of Nigeria conference, Ayetoro, Nigeria.

Bell, W. E. (2003). "Consumer Innovators: A Unique Market for Newness," in Toward Scientific Marketing, ed. Stephen A. Greyser, Chicago: American Marketing Association, p.90-93.

CBN (2007). Statistical Bulletin. Central Bank of Nigeria.

CBN (2014). $80 \%$ Of Nigerian Youths Are Unemployed - CBN Official. http://www.informationng.com/tag/national-bureau-of-statistics

Chigbu, U. E. (2000). Agriculture as the only saviour to Nigeria dyeing economy. http://www.nigerianvillagesquare.com/articles/guest/2005/03/agric-as-only-saviour-to-nigeria-dyeing-econo my.html

Eze, F. J., Ehikwe, A. E., \& Odigbo, B. E. (2015). Strategy for small and medium scale enterprises (SMES) during economic down-turn in Nigeria. Asian Academic Research Journal of Social Sciences \& Humanities, l(34), 1-12.

Eze, F. J., Odigbo, B. E., \& Ehikwe, A. E. (2015). Marketing Communications Strategy for Curbing Youths'Unemployment through Farming in Nigeria. Journal of Economics and Sustainable Development 6(16), 44-55.

Katz, E., \& Lazarsfeld, P. (2005). Personal influence: The part played by people in the flow of mass communications, Glencoe: Free Press.

Lazarsfeld, P., Berelson, B., \& Gaudet, H. (2004). The People's Choice. New York: Duell, Sloan and Pearce.

NBS (2013). 54\% of Nigerian Youths Were Unemployed in 2012. http://www.informationng.com/tag/national-bureau-of-statistics

Newsheadline (2015). Buhari Announces 'Covenant With Nigerians, http://www.newsheadline.com.ng/blog/2015/03/17/buhari-announces-covenant-with-nigerians/

Nigerianmonitor (2015). My 100 Days Covenant With Nigerians - Muhammadu Buhari http://www.nigerianmonitor.com/2015/01/11/my-100-days-covenant-with-nigerians-muhammadu-buhari/

Odigbo, B., Ugwu, O. S., \& Ekemezie, L. I. (2017). Effect of Mass Media and Africa Traditional Media on HIV/Aids Prevention Social Marketing Campaigns in Nigeria. International Review of Management and Business Research, 6(2), 707-716.

Ogunkola, E. O., Bankole, A. S., \& Adewuyi, A. (2008). China-Nigeria Economic Relations, AERC Scoping Studies on China-Africa Relations [Revised Report submitted to the African Economic Research Consortium (AERC), February, 2008. http://www.aercafrica.org/documents/

Omeje, K. (2005). Youths, Conflicts and Perpetual Instability in Nigeria, http://www.hollerafrica.com/showArticle.php?artId=18\&catId=3

Pandey, S., \& Yadama, G. N. (2002). "Community development programs in Nepal: a test of diffusion of innovation theory." Social Service Review, 23(7), 112.

Rise Network (2013). Youth Unemployment in Nigeria: Shocking Statistics, Facts and Why the Future May Not Be So Bright After all.

http://risenetworks.org/2013/05/16/youth-unemployment-in-nigeria-is-there-hope-for-nigerian-youth/

Rogers, E. M. (2003). Diffusion of innovations (5th edition). New York, NY: Free Press.

Schneidman, W., \& Lewis, Z. A. (2012). The African growth and opportunity act looking back, looking forward: 
Africa growth initiative at Brookings.

United States International Trade Commission Trade and Tariff Data web (2011).

Valente, T. W. (2006). "Social network thresholds in the diffusion of innovations." Social Networks, 18(1), January 1996, 69-89.

\section{Copyrights}

Copyright for this article is retained by the author(s), with first publication rights granted to the journal.

This is an open-access article distributed under the terms and conditions of the Creative Commons Attribution license (http://creativecommons.org/licenses/by/4.0/). 